\section{Relationship between mood disturbances and free and total plasma tryptophan in postpartum women}

Mild disturbances of mood occur in $50-70^{\circ}{ }_{0}$ of women in the postpartum period, ${ }^{1}$ when they may begin to cry for no apparent reason. The crying may be intense and prolonged and may often, but not always, be associated with a depressed mood. The synthesis of brain 5-hydroxytryptamine (5-HT) may be decreased in depressive illness, and the precursor of central 5-HT is brain tryptophan, which is probably derived from free plasma tryptophan. ${ }^{2}$ Lowered levels of free plasma tryptophan have been reported in depression, ${ }^{3}$ and we have examined the relation between free plasma tryptophan levels and affective changes in the puerperium.

\section{Patients, methods, and results}

We invited 18 women in a postnatal ward to participate. During their seven or eight days in hospital they rated themselves daily from 0 to 4 for each of the following five symptoms: tearfulness (no tears to cried for more than 30 minutes); depression (no depression to very depressed); anxiety (normal anxiety to desperately anxious); appetite (normal to complete loss); insomnia (good night's sleep to very disturbed sleep). An average daily score for each symptom for every patient was calculated, and the sum of the average daily scores for each symptom provided an average daily "total affective score." Thus the maximum possible average daily score per symptom was 4 , and the maximum daily total affective score was 20 , which enabled the patients to be ranked in order of increasing affective disturbance.

On the sixth day postpartum a $30-\mathrm{ml}$ fasting blood sample was taken from each patient, a pilot study having shown that mood disturbance is most severe then. None of the patients were receiving drugs. For comparison, groups of normal controls and depressed inpatients were also studied. Laboratory staff who were unaware of the psychiatric state of the patients at the time estimated the free plasma tryptophan and total plasma tryptophan levels in the puerperal women, normal controls, and depressed patients using the same laboratory and methods. ${ }^{4}$ There was no correlation between age and free plasma tryptophan in any of the three groups. The table shows groups of postpartum patients in order of increasing affective disturbance together with their tryptophan levels.

Patients who appeared clinically to have severe depression (ranks 15-18) had free plasma tryptophan levels similar to those found in depressive illness. Only one of the remaining patients (rank 7) had a low free plasma tryptophan level $(4.60 \mu \mathrm{mol} / 1(0.94 \mu \mathrm{g} / \mathrm{ml})$; free :bound plasma tryptophan $=0.055)$, and she appeared to be clinically hypomanic. Free plasma tryptophan correlated significantly with depression $(\mathrm{r}=-0.60 ; \mathrm{P}<0.01)$ and also with the total affective score $(r=-0.49 ; P<0.05)$. The other symptoms showed similar trends but the correlation failed to reach statistical significance. Total plasma tryptophan did not correlate with any of the clinical data but was $33.5 \%$ higher than in the controls.

\section{Comment}

These results show a significant correlation between the severity of affective disturbances and free plasma tryptophan levels. Hence mood changes in the postpartum period may be mediated by changes in brain 5-HT and free plasma tryptophan, as may be the case with depressive illness.

Decreased 5-HT turnover has been reported in hypomania, and the one patient in our series who appeared to be hypomanic had a low free plasma tryptophan level. The reason for the high total tryptophan in the plasma of postpartum women is unknown, but this high level is consistent with what has been found in animals. Thus in a study of the brains of parturient mice on the fifth day postpartum, lowered levels of 5-HT and 5-hydroxyindoleacetic acid were found together with a raised total brain tryptophan level. ${ }^{5}$ The biochemical mechanisms causing these alterations in tryptophan metabolism are unknown but may be related to the considerable changes in oestrogen and progesterone secretion that follow delivery.

We thank Mr P L Diggory, Mr J Macgrath, and Mr D Fairnburn for encouraging us to study the patients under their care, and gratefully acknowledge the help of Sister M Stuart-Menteth, Mr E Eccleston, Miss M E Bishop, Mrs J Harwood, and Mr J E Bailey.

Requests for reprints should be addressed to: Dr G Stein, Maudsley Hospital, Denmark Hill, London SE5 8AZ.

1 Yalom, I D, et al, Archives of General Psychiatry, 1968, 18, 33.

2 Tagliamonte, A, et al, Life Sciences, 1973, 12, 277.

${ }^{3}$ Coppen, A, Eccleston, E G, and Peet, M, Lancet, 1973, 2, 60.

${ }^{4}$ Eccleston, E G, Clinica Chimica Acta, 1973, 48, 269.

5 Greengrass, P M, and Tong, S R, British fournal of Pharmacology, 1972, 46, 533.

Kingston Hospital, Kingston upon Thames, Surrey

GEORGE STEIN, MRCP, DCH, psychiatric registrar

FRANK MILTON, BA, psychologist

PENNY BEBBINGTON, BA, psychologist

MRC Neuropsychiatry Laboratory, West Park Hospital, Epsom KT19 8PB, Surrey

KEITH WOOD, PHD, biochemist

ALEC COPPEN, MD, FRCPSYCH, director

\section{Treatment of childhood asthma with sodium cromoglycate and beclomethasone dipropionate aerosol singly and in combination}

Inhalation of sodium cromoglycate (SCG) and beclomethasone dipropionate aerosol each reduces the frequency and severity of asthmatic symptoms in children. ${ }^{12} \mathrm{~A}$ comparison of these drugs in patients previously untreated with either drug has not been reported, however, and no advantage has been shown from combining them. We have therefore compared the protective effects of these drugs and studied the possible benefits of combining them.

\section{Patients, methods, and results}

Eleven boys and three girls participated in the trial with parental consent They suffered recurrent attacks of wheeze and dyspnoea inadequately controlled with bronchodilators but had not required oral corticosteroids. All had at least one positive skin test result. The mean age at the start of the trial was 8.9 years (range $5 \cdot 2-15 \cdot 0$ years).

The study was double-blind. All patients were given placebo SCG and placebo beclomethasone aerosol for the first two weeks to ensure that the parents could complete diary cards correctly and that the children were using their inhalers satisfactorily. Thereafter each patient had 12 weeks on each of the three treatment regimens (see table) in random order. Separate records were kept by the parents of the severity (scale 1-4) of diurnal and nocturnal wheezing during every 24 -hour period. At four-week intervals the patients were reviewed by one of us. Inhaler technique was checked, the chest was examined, diary cards were scrutinised, and the forced expiratory

Mean plasma tryptophan levels in the 18 postpartum patients ranked in order of increasing severity of affective disturbances. Levels in 16 normal women controls and 50 women with endogenous depression are given for comparison. All figures are expressed $\pm S E$

\begin{tabular}{|c|c|c|c|c|c|c|}
\hline & & $\begin{array}{l}\text { Mean total } \\
\text { affective score }\end{array}$ & $\begin{array}{c}\text { Mean age } \\
(\text { years })\end{array}$ & $\begin{array}{l}\text { Free plasma tryptophan } \\
(\mu \mathrm{mol} / 1)\end{array}$ & $\begin{array}{l}\text { Free :bound } \\
\text { plasma tryptophan }\end{array}$ & $\underset{(\mu \mathrm{mol} / \mathrm{l})}{\text { Total plasma tryptophan }}$ \\
\hline \multirow[t]{2}{*}{$\begin{array}{l}\text { Postpartum patients } \\
\text { (rank Nos) }\end{array}$} & $\left\{\begin{array}{l}1-5 \\
6-10 \\
11-14 \\
15-18\end{array}\right.$ & $\begin{array}{l}0.75 \pm 0.10 \\
1 \cdot 79 \pm 0.09 \\
2 \cdot 31=0.14 \\
5 \cdot 10 \pm 0.90\end{array}$ & $\begin{array}{l}27 \cdot 6 \pm 2 \cdot 7 \\
29 \cdot 6 \pm 3 \cdot 0 \\
25 \cdot 8 \pm 0 \cdot 6 \\
25 \cdot 0 \pm 1 \cdot 7\end{array}$ & $\begin{array}{r}7.00 \pm 0.93 \\
6.51 \pm 0.54 \\
6.76 \pm 0.59 \\
4.36^{*} \pm 0.49\end{array}$ & $\begin{array}{r}0.094 \pm 0.012 \\
0.084 \pm 0.010 \\
0.082 \pm 0.003 \\
0.058^{* *} \pm 0.007\end{array}$ & $\begin{array}{r}82 \cdot 3 \pm 4 \cdot 1 \\
86 \cdot 7 \pm 4 \cdot 2 \\
89 \cdot 1 \pm 5 \cdot 5 \\
80 \cdot 8^{* *} \pm 5 \cdot 3\end{array}$ \\
\hline & $\left\{\begin{array}{l}1-14 \\
1-18\end{array}\right.$ & $\begin{array}{l}1 \cdot 57 \pm 0 \cdot 19 \\
2 \cdot 35 \pm 0 \cdot 42\end{array}$ & $\begin{array}{l}27 \cdot 8 \pm 1 \cdot 5 \\
27 \cdot 4 \pm 1 \cdot 2\end{array}$ & $\begin{array}{r}6.76 \dagger \pm 0.39 \\
6 \cdot 22 \pm 0.39\end{array}$ & $\begin{array}{l}0.087+\dagger \pm 0.010 \\
0.080^{* *} \pm 0.005\end{array}$ & $\begin{array}{r}85 \cdot 7 \pm 2 \cdot 5 \\
84 \cdot 7^{* *} \pm 2 \cdot 3\end{array}$ \\
\hline \multicolumn{2}{|c|}{$\begin{array}{l}\text { Normal women controls } \ldots \\
\text { Women with endogenous depression }\end{array}$} & & $\begin{array}{l}25 \cdot 6 \pm 0 \cdot 8 \\
55 \cdot 2 \pm 1 \cdot 9\end{array}$ & $\begin{array}{l}5.93 \pm 0.34 \\
4.06 \pm 0.20\end{array}$ & $\begin{array}{l}0.118 \pm 0.010 \\
0.075 \pm 0.003\end{array}$ & $\begin{array}{l}56 \cdot 3 \pm 1 \cdot 6 \\
59 \cdot 7 \pm 1 \cdot 5\end{array}$ \\
\hline
\end{tabular}

